\title{
BLUE BOOKS*
}

\author{
BY \\ SIR JOHN GHARLES, K.G.B., M.D., F.R.G.P. \\ Chief Medical Officer of the Ministry of Health
}

BLUE Books! The appropriate commentary is probably the Latin tag from the Eneid, the observation which Virgil applies to the appearance of the sea-serpents-horresco referens!

Even more apposite, perhaps, is the inscription which Dante found on the lintel of Hell-'All hope abandon, ye who enter here!' But what are Blue Books? Under this popular name, and the more official title of 'Parliamentary Papers' are comprised a vast mass of documents, which provide some of the necessary material for the deliberations of Parliament.

The verbatim daily records of the debates of the two Houses, and the annual narrative summary of their Acts are referred to respectively as 'Hansard' and the 'Journal', and are not usually regarded as coming within the category of Parliamentary Papers. The latter include the Estimates and Accounts, the annual reports of Ministries and Standing Commissions, the proceedings and recommendations of Royal Commissions, the vital statistics of the Registrar-General, the great corpus of national statistics, economic and commercial and much other documentation, all of which is essential to the proper transaction of the work of Parliament, and to a well-founded knowledge of the welfare of the State and its citizens. In the middle of last century many of these publications which had been prepared for the purposes of Parliament, but were also available for purchase, appeared in robust dark-blue covers, which obtained for them their popular title. Today a smaller proportion are to be seen in the traditional blue dress; others, the White Papers, are issued without covers at all, or with a cream or buff backing. Whether they are published plain or coloured, whether they are selected by custom or convention for the familiar blue binding, does not seriously matter-all are Parliamentary Papers.

A negative sort of fame, not always deserved, attaches to Blue Books-a reputation for dullness and heaviness. But they have earned contrary opinions in certain quarters. A report on Parliamentary Papers which appeared in 1825 contains this testimonial:

In these Reports there is scarcely a subject connected with the Laws, Institutions, Commerce and Morals of the country but what will be found treated on: the Administration of Justice, the Privileges of Parliament, the National Church, Arts and Manufactures, Agriculture and Trade, Criminal Law, Police, and Educationall have their place. ${ }^{1}$

* An Address to the Medical Section of the Library Association, June I3, I956. 


\section{Sir John Charles}

Elsewhere it has been said:

Blue Books give information of new discoveries; they are official records of the complaints of society; they gather from all quarters illustrations of the evils which Parliament is asked to remedy. ${ }^{2}$

They are therefore to be regarded as amongst the basic historical documents, the authentic source of material in which one can trace the trends and movements in almost every phase of the national life.

I do not propose to conduct you on a protracted tour of the now enormous library of Parliamentary Papers, or even to linger unduly in that small cabinet which houses the Blue Books that are of interest to medicine or the public health. On a conservative estimate even the latter contains at least a thousand separate publications. The great majority of them are no longer of importance, except to the historian for whom nothing has a purely ephemeral interest. But a gentle excursion through the pages of some of the more noteworthy will serve to show how step by step government came to recognize its duty as the custodian of the public health.

Particularly in the Blue Books of the Victorian era one can read the vivid, rotund phrases which served to mould parliamentary and public opinion, and then note their translation, at a later date, into the formal clauses of legislation. There is a greater sobriety, a less evangelical flavour about more modern publications, but even they are not without their purple passages. The first British Blue Book with a medical connotation was published on 27 June 1831 -its price $I s$.; its long title 'Information relating to Infectious Diseases prevailing in the Eastern parts of Europe, and the precautions recommended to prevent their introduction into this country'; its subjectcholera. ${ }^{3}$ It was the first of a series of thirty-two government publications which between 1831 and 1900 dealt with the problems raised by cholera, and by its epidemic visitations and threats to these islands. Until the last decade of the nineteenth century cholera remained 'the pestilence that walked in darkness and destroyed in the noon-day', and the two words morbus cholerae at the top of a column of a middle page of The Times were an effective memento mori.

The story behind the $183 \mathrm{I}$ Blue Book is interesting. Early in that year when it became known in London that cholera had spread from Astrakhan and the Caspian into the heart of European Russia, their Lordships of the Privy Council commissioned an English doctor, Thomas Walker, domiciled in St. Petersburg, to furnish a report. Dr. Walker accordingly embarked upon a seven weeks' mission which took him to Moscow and beyond. He had his adventures, for part of his journey was made by boat up the icestrewn Volga; he attended post-mortems, and learned little from them; he himself felt that cholera was a disease transmitted by human contacts, but 


\section{Blue Books}

on this he differed from his Russian and German colleagues, who tended to depreciate the importance of the disease and to doubt its infectious character. Except as the initial landmark, Dr. Walker's Blue Book is not important, but from its successors one can trace the whole history of cholera in Great Britain, and in the areas of the world from which it might be imported, until its final disappearance from these shores. The occasion of a Blue Book might be the prevalence of the disease in Jamaica, Egypt, Malta or the Gambia; it might be its treatment by metropolitan, provincial or homoeopathic methods; it might be the discovery by Dr. Thudichum of spectroscopic changes in the urine of cholera patients. The last report in the seriespublished in 1900-records a British triumph in preventive medicine-the success of the vaccines of Leishman and Wright in conferring immunity against cholera and typhoid also."

\section{EDWIN GHADWICK}

One of the greatest masters of the gentle art of propagating Blue Books was that phenomenon of energy and misdirected zeal, Edwin Chadwick. For the twenty years between 1834 and 1854 Chadwick pervaded and dominated the administration of the Poor Law in this country, and fanned the first glowing sparks of the sanitary idea into life. He came to understand the environmental and social evils of the time through his intimate knowledge of the way in which the poor lived. Much of this was personal experience; much of it came from the written reports of inspectors and colleagues, who carried out country-wide investigations into the sanitary conditions of the labouring classes.

The detail of these inquiries constitutes the first major Blue Book of the new sanitary era. There were three separate volumes, two being local reports for England and Scotland respectively; the third, a synoptical compendium, was the work of Edwin Chadwick, and remains distinctively his. ${ }^{5}$ Its $45^{\circ}$ pages were procurable at the price of $75.6 d$., and in all 10,000 copies were sold or distributed. For a generation this magnum opus of Chadwick's was the repository of tradition and experience for the sanitary reformers, and a text-book for budding sanitary engineers. One French newspaper editor found it too highly seasoned for his readers. It is certainly as compact a chronicle of horrors as one could wish to encounter.

Let us follow its author into a Glasgow wynd.

We entered a dirty low passage which led to a square court, which court with the exception of a narrow path round it, was occupied as a dung receptacle of the most disgusting kind. There were no privies or drains, and the dung heap received all the filth which the swarm of wretched inhabitants could give. We learned that a considerable part of the rent of the houses was paid by the produce of the dung heaps. 


\section{Sir John Charles}

It was in Glasgow that some children when asked for their names became hesitant and confused. The comment of the Superintendent of Police was as follows:

The fact is they really have no names. Within this range of buildings, I could find a thousand children, who have no names whatever or only nick-names like dogs.

Here is the description of the habits of the 598 bone-pickers and muckrakers who were known to the police in Manchester:

The bone-pickers are the dirtiest of all. ... I have seen them take a bone from a dung heap, and gnaw it reeking hot with the fermentation of decay. Bones are scraped carefully ... and the thin strip of flesh adhering to them, no matter how befouled with dirt are placed in a wallet. ... Whether in broth or grilled they were the most savoury dish that could be imagined.

Let us look at the section headed 'Circumstances in the internal economy and bad ventilation of places of work unfavourable to health'. Mr. Thomas Brownlow, a tailor, takes part in this catechism:

What was the effect of the state of the work-places upon the habits of the workmen?

Mr. Brownlow replies:

It has a very depressing effect on the energies. The natural effect of the depression was that we had recourse to drink as a stimulant. We went into the shop at 6 a.m. but at 7 a.m. when orders for breakfast were called for, gin was brought in, and the common allowance was half-a-quartern ( $2 \frac{1}{2}$ ozs.).

When again was liquor brought in? [continues the questioner].

At II a.m. Some took beer, some took gin again. In a general way they took a pint of porter. It was seldom that men took more than the half-quartern of gin.

\section{When again was liquor brought in?}

At 3 p.m., when some took beer and some gin, just the same as in the morning. At 5 p.m. the beer and the gin came in again, and was usually taken in the same quantities. At 7 p.m. the shop was closed.

Are gin and beer the only stimulants taken in consequence of the want of ventilation?

No, snuff is very much taken as a stimulant; the men think that snuff has a beneficial effect on the eyes.

It was by the creation of such pen-pictures, by emphasis, and reiteration that Chadwick sought to obtain the institution of proper sanitary legislation.

By way of an after-thought he produced in 1843 a report on 'The Practice of Interment in Towns' ${ }^{6}$ For the price of $2 s .6 d$. one could buy a 270-paged Blue Book which considered in the most minute detail all the elaborate and 


\section{Blue Books}

costly trappings of mortality. Nothing was omitted. Against a background of incidentals, the explosions of lead coffins in the vaults of cemeteries to the alarm of neighbouring residents, the legal decision of Lord Stowell which prohibited the use of iron coffins because they gave their tenants too durable a domus ultima, the pollution of the Houses of Parliament by the tide-drawn mephitic vapours from St. Margaret's Churchyard, Chadwick, developed the main points of his argument, the danger to the public health of many of the current practices relating to the disposal of the dead, and the inordinate cost of privately organized funerals and interments. One quotation will suffice to illustrate his first grievance:

With the upper classes a corpse excites feelings of awe and respect; with the lower orders it is often treated with as little ceremony as the carcase in the butcher's shop. Nothing can exceed their desire for an imposing funeral, but the deceased's remains share none of the reverence. The inconsistency is to be attributed to a single circumstance-the body is never absent from their sight. (In parenthesis one should add that the corpse usually remained unburied for at least a week.) Eating, drinking, or sleeping it is still by their side, mixed up with all the functions of daily life. The body stretched out upon two chairs is pulled about by the children, made to serve as the resting place for any article that is in the way, and is not seldom the hiding place for the beer-bottle or the gin if any visitor arrives inopportunely.

As a result of his inquiries Chadwick estimated that the annual expenditure on funerals in England and Wales was $£ 4,871,493$. In arriving at these figures he discovered much interesting and recondite information. For example, he learned that the marshalling of a nineteenth-century funeral followed strictly the old heraldic order for a baronial funeral. The two men standing at the door of the house corresponded to the porters of the castle; the man heading the procession wearing a scarf represented a herald-at-arms, the man with the plume of feathers was the esquire, the pall bearers with their batons took the place of the knights' companions-at-arms. Each of these dignitaries received a special fee for his services and the hire of his trappings. Amongst the recipients of perquisites were the officiating clergy. The 'usual' given to the clergyman consisted of a silk scarf of three and a half yards, a silk hatband and black kid gloves, but these tributes were often commuted for a fee of from I8s. to 24s. With these schedules of attendants and charges the funeral of an attorney with twenty attendants would cost 100 guineas, but the obsequies of a person of the condition of a gentleman might entail an expenditure from $£ 200$ to $£ \mathrm{I}, 000$.

Chadwick had no doubt as to remedies for these evils. It was in effect the nationalization of the industry. He worked out his plan in meticulous detail even to the extent of suggesting a national liturgy for the burial of the dead with recommendations as to appropriate music. It was done solemnly 


\section{Sir John Charles}

without any intention of levity, but some of his proposals and lyric touches have stimulated the risibility of succeeding generations.

The great body of English poetry [says Chadwick] which is more rich on the subject of sepulture than the poetry of any other nation, abounds with references to the practice of ornamenting graves with flowers, shrubs and trees. A rich vegetation exercises a powerful purifying influence and where the emanations are moderate as from single graves, would go far to prevent the escape of any deleterious miasma.

And again on the subject of the special difficulties of sepulture in London:

It might be found that the banks of the river present several eligible sites for national cemeteries, and one pre-eminent recommendation of such sites would be the superior and economical means of conveyance they would afford by appropriate funeral barges, for uninterrupted and noiseless passage over 'the great silent highway' of the Thames.

What did Chadwick achieve through these reports and their accompanying propaganda? His excursion into the field of necrology brought little except the sceptical ridicule of the House of Commons. But in the broader field he obtained a Royal Commission on the Health of Towns which reported in February $1845,{ }^{7}$ and begat the first Public Health Act of 1848 . From that Act came the Medical Officer of Health as we know him today, and the establishment of the General Board of Health, with Mr. Chadwick as a member.

It is perhaps a simplification of history but sufficiently true for our purpose to regard the General Board of Health as the short-lived and somewhat turbulent ancestor of our present Ministry of Health.

\section{WILLIAM FARR}

Contemporary with Edwin Chadwick, though by no means his congenial and ever-willing collaborator, was William Farr, the gentleman of the medical profession, who in 1839 was appointed by the Registrar-General to be the compiler of abstracts from the dates of births, marriages and deaths.

Farr, a poor Shropshire boy, who had the good luck to be educated for medicine by a neighbouring gentleman farmer, became the greatest medical statistician that this or any other country has ever produced.

Equipped with relatively slender medical qualifications, Farr had a number of other gifts, certainly not common amongst the medical men of his times. He was an adequate mathematician, a man of wide reading and culture with a command of several languages and of their literature; he was possessed of a lively imagination and an untiring pen, he had an attractive, and at times eloquent choice of English, and above all displayed a vigorous and crusading interest in the health of the people. 


\section{Blue Books}

The many hundred pages of his writings include the narrative descriptions and commentaries relating to three censuses, and some forty annual reports to the Registrar-General. But apart from these official contributions, he gave without stint to any sympathetic inquirer, and every prospector in the sanitary wilderness-Chadwick, Simon, even Florence Nightingalecame to depend upon him for those apt numerical illustrations which crystallized their ideas and gave them new vitality.

In his first annual report are to be found these words, which like a Wagnerian leitmotif are woven into so much of his later writing:

Diseases are more easily prevented than cured, and the first step to their prevention is the discovery of their exciting causes. For diseases are the iron index of misery, which recedes before strength, health and happiness as the mortality declines. ${ }^{8}$

In that same report he gave tongue to certain hopes which we, with more solid grounds for optimism, can now claim to be substantially achieved:

The registration of the Causes of Death will give greater precision to the principles of Physic. Medicine like the other natural sciences is beginning to abandon vague conjecture where facts can be accurately determined by observation. Loose phrases are still current for which numerical formulae will be substituted. ${ }^{\circ}$

There are scores of similar obiter dicta, but Farr is at his best in those longer passages where in grim yet glowing colours he paints the hazards of life amongst the slums, miasmata and cesspools of the metropolis. Here is an extract from the Annual Report to the Registrar-General for 1847:

Now the plain truth is, that one day with another I 34 persons die daily in London; that the great majority are untimely deaths-children, fathers, mothers in the prime of life; and that at least 38 die daily in excess of the rate of mortality . . . in the immediate neighbourhood. If these deaths took place on London Bridge or at Newgate, would any sensible man oppose any reasonable measure devised by a Minister of the Crown to put a stop to the frightful sacrifice of life.

But the city itself, it is said, is as healthy as can be; the authorities have done everything that can be done. Has the Lord Mayor ascertained this by personal inspection? He has the conservancy of the swans and the fish of the Thames, and so weighty has this duty been ... that the first magistrate attended by the civic authorities proceeds periodically to hold courts of inspection and to ascertain the condition of these creatures. If some time after having been 'To Thames's banks which fragrant breezes fill' and seen the white swans on the river, on landing from his barge ... they would proceed ... through alleys and lanes and up courts inhabited by citizens of London, ... they would pass through streets on which the sun rarely shines, houses saturated with pestilential vapours-the most fatal field of fever in the metropolis. They would see disease gleaming in the eyes of the children, wasting the bodies of the women, prostrating the strength of the men. ${ }^{10}$ 


\section{Sir Fohn Charles}

\section{JOHN SIMON AND HIS GOLLEAGUES}

From I 855 we encounter yet another begetter and instigator of Blue Books in John Simon, born in England, but more than half French by parentage. He had been made a Fellow of the Royal Society at the age of twentynine, and later became Pathologist and Surgeon to St. Thomas's Hospital, and part-time Medical Officer of Health for the City of London. Before he joined the General Board of Health in the autumn of 1855 he had written a sheaf of clinical lectures for The Lancet and the first English text-book on pathology. As the whole-time salaried Medical Officer of the Board he undertook to abstain from private practice, but, by agreement, he continued to act as Surgeon to St. Thomas's Hospital, with all that that involved in the clinical care of patients and the instruction of medical students.

In 1858 the General Board of Health was superseded by the Medical Department of the Privy Council, but Simon retained his appointments, both in Whitehall and at St. Thomas's. Twelve months later he commenced that series of reports which year by year since that date has provided an Annual Chronicle of 'The State of the Public Health in England'.

Those blue-covered volumes, particularly for the years between I 859 and I870, are still a repository of experience, observation and learning - a vivid social and medical history of the times which has no superior, and hardly a peer in any language. The topics treated fall into two main categoriesthe excess of disease and the necessaries of health.

Under the first heading are to be found reports on diphtheria, yellow fever in South Wales, famine-created disease amongst cotton workers in Lancashire, occupational hazards of needlewomen, tailors, printers and match-makers and, on infant deaths in town and country.

In the second group came investigations into the food interests of the country as a whole-into-as Simon phrases it-"the minute economics of diet", with elaborate studies of local dietaries. Other subjects were the dwellings of the labouring classes and the state of the hospitals, the latter producing some pungent comments on their comparative successes and failures in treatment. In another vein was a classical report on 'Safeguards against accidental and criminal poisoning'.11

Each annual report contained the record of a number of separate investigations carried out, in the main, by Simon's part-time colleagues, many of whom came to fill posts of the highest distinction and authority in the academic and clinical branches of medicine. It is interesting to note the broadening of the medical mind, its movement from cholera, fever and the associated environmental horrors, into realms where economic conditions, social circumstances and industrial employment were all regarded as of 


\section{Blue Books}

aetiological significance. The prefaces to the reports were the work of Simon himself, and his polished summaries and commentaries are the source of innumerable quotations.

Let us dip into the treatise of Dr. Edward Smith on 'The Food of the Poorer Labouring Classes' which is to be found in the report for $1863 .{ }^{12}$ Smith had toured the four kingdoms, and was able to compare the farm labourers and their families in each. He based his conclusions upon a most detailed tabulation of all the facts, size of family, income, rent, composition of the week's dietary, and analysis of its constituents in terms of carbon and nitrogen per head. It makes strange reading to learn that labourers in the farm-houses of England had usually four full meals each day. Puddings or pies were supplied twice daily in Devon; cheese-cake and custard at breakfast and dinner in Yorkshire, where the men were allowed a nap of an hour after their midday meal. In Scotland, however,

the labourers were slow either to appreciate the object of the inquiry, or to make the required estimates ... so that it was needful to exercise much patience and whatever tact might be possessed, and to give as much time to each case as would have obtained the answers from three cases in England.

The consumption of oatmeal in a mixed diet was $7 \mathrm{lb}$. per adult weekly, but reached $17 \frac{1}{2} \mathrm{lb}$. where no other bread stuff was eaten. The value of the meat of lambs and sheep dying of an acute disease termed 'braxy' was the subject of much debate. There were differences of opinion as to its 'healthfulness and savouriness', but these differences arose on the degree of decomposition which determined its fitness for human consumption. There was 'some sense of shame on the part of those who ate it', but there could 'be no doubt that it had been eaten from time immemorial in the Highlands'.

In Ireland Dr. Smith found the

population, although wearing an aspect of greater wretchedness to English eyes, to be a fine, well-built and often athletic race, with children sufficiently fleshy and rosy, and bearing all the marks of health. The wife, moreover, was usually more robust and healthy looking, than is observed in England.

Potatoes were the main essential item of the dietary.

When the season arrives at which they are plentiful they commonly supplant every other farinaceous food, and with buttermilk constitute the sole food of the peasantry.

In a family consisting exclusively of grown-ups, 10 $\frac{1}{2} \mathrm{lb}$. was consumed daily by each man.

There could be no doubt from the testimony of all classes that potatoes were a most highly prized food ... and one in which they indulge as largely as the supply and the enlarged capacity of their stomachs will admit of ... 


\section{Sir John Charles}

Dr. William Miller Ord, in his report on the 'Sanitary Gircumstances of Dressmakers and other Needlewomen in London', ${ }^{13}$ reviewed the list of dressmaking firms, the number of hands employed, their grades and system of promotion, their hours of work, food, exercise and holidays, their bedrooms and work-places, their wages. He catalogued their most frequent indispositions and diseases, headaches, giddiness, dyspepsia, phthisis, hysteria and defects of vision.

The facts of industrial fatigue were familiar to Dr. Ord.

Morning work [said he] is always the best, and the better the work the shorter the hours. For in the early day the fingers move more rapidly . . . the mind receives instructions more clearly, and so little work has to be undone.

But outside events could influence output.

With reference to the great extension of hours which precedes Her Majesty's drawing rooms (when the normal day ending at ro p.m. would be much prolonged) girls have asserted ... that they enjoy the excitement of such nights, unless too often repeated; the furious haste with which the work is pushed on, the speculation as to whether it will be finished in time, and the additional refreshments provided on such occasions, have, apparently, some charm for minds wearied with monotonous toil, and in the tradition of some work-rooms these-long nights are certainly connected with pleasant recollections.

Next let us look at the report of Dr. Henry Julian Hunter 'On the Excessive Mortality of Infants in some Rural Districts of England' ${ }^{14}$ (At that time infantile mortality rates of from 200 to 240 per I,000 born were by no means uncommon.)

The causes of this high mortality were, briefly, employment of mothers on the land, premature births amongst those engaged on field labour, bastardy and opium.

One source of advantage in the employment of women in agriculture was:

the superior management ... they show in combining their work with that of boys and girls, and this ... has led to the frequent formation of what are called 'gangs' ... who work together for a stated sum paid by the farmer to a man called the undertaker... These gangs will sometimes travel many miles from their own village; they are to be met morning and evening on the roads, dressed in short petticoats, with suitable coats and boots, and sometimes trousers, looking wonderfully strong and healthy, but tainted with a customary immorality, and heedless of the fatal results which their love of this busy and independent life is bringing on their unfortunate offspring, who are pining at home.

Large numbers of children were literally starved to death as a result of the feeding habits of the mothers. Worse than the starvation was the constant 


\section{Blue Books}

drugging with opium. This was particularly common in the Fens, where the anti-malarial and anti-rheumatic uses of the drug was traditional; but it was not limited to East Anglia. That particular area, however, was remarkable in that 'to meet the popular taste, but to the extreme inconvenience of strangers, narcotic agents were put into the beer by the brewers'. The favourite form of opium for infants was:

Godfrey's Cordial, a mixture of opium, treacle and infusion of Sassafras. When the mother going to field work deposits her child with a nurse, she thinks it best to leave her own bottle of Godfrey, because the preparations of the different shops vary, and there is not a little village shop ... that does not sell its own 'Godfrey'.

It has not infrequently happened that a nurse has substituted her own "Godfrey" for her clients, and frightened at its effects has summoned the surgeon who finds half a dozen babies, some snoring, some squinting, all pallid and sunken eyed, lying about the room, all poisoned.

Ghildren treated in this way 'shrank up into little old men, others became wizened like little monkeys'. Many died. One more fortunate, reared on 'Godfrey', became a well-known living skeleton, travelling from fair to fair.

And finally here is Simon himself, gathering together all the threads of these discourses, assessing the personal, environmental and social circumstances conducive to these evils, and indicating where in these matters medicine stands, and where government.

How far the described circumstances of our poorest labouring populations tend to better themselves, and how far they may be bettered by interference without, are questions which cannot be discussed without reference to parts of political economy on which I am incompetent to speak.

Indirectly, indeed, these questions are of the vastest sanitary importance: for the 'public health' of a country means the health of its masses, and the masses will scarcely be healthy unless ... they be at least moderately prosperous. And although the satisfactory solution of these questions is a task for other sciences than the science of medicine ... yet assuredly if that solution can be given the ultimate result will be among the foremost gains which a department of public health can have to record.

Simon's appeals were not in vain. Several years later when reviewing the fruits of these classic Blue Books he was able to say:

Our exposure of so much gross insufficiency in the laws which purported to protect the public health was speedily followed by legislation of the highest practical importance. ${ }^{15}$

Not only did this legislation comprise the great Sanitary Act of I866-the Act of the imperative mood which ascribed 'duties' as well as 'powers' to Local Authorities, but a Factories and Workshops Act, and a Merchant 


\section{Sir John Charles}

Shipping Act which sought to give to merchant seamen some modicum of protection against sanitary neglects and the assaults of scurvy. It also begat a 'Pharmacy Act' which improved pharmaceutical practice, and interfered materially with the ploys and crafts of the poisoner.

Later there came through the activities of another Royal Commission the Public Health Act of 1875, which in the words of Professor W. M. Frazer:

'covered the whole of the legislative needs in the field of sanitation of the age in which it was passed' and manifested 'a quality of permanence which had been significantly wanting' in earlier legislation. ${ }^{16}$

\section{INTERDEPARTMENTAL GOMMITTEE ON PHYSICAL DETERIORATION}

In May 1876 , Simon, still some six months short of the age of sixty, retired from his official position in Whitehall. There remained much for him to do in other fields. For two years he was President of the Royal College of Surgeons. Even before 1858, when the first Medical Act was passed, he had been the éminence grise behind the improvement of medical education in this country, and in 1876 , released from official duties, he became a member of the General Medical Council and influenced materially, if he did not dominate, its deliberations for the next twenty years! He lingered on, an old man almost blind, until 23 July 1904. At his death in his eighty-eighth year there were those who remembered his name and his work as a dim echo from the past. But no man in any country at any time had done more for the art and profession of medicine or for the alleviation of the burdens and sorrows of his fellow-countrymen. Three days before Simon's death, there appeared the last report of these official committees or commissions, whose deliberative cogitations have been embodied-and sometimes embalmed-in Blue Book form, and from which I propose to cull and to quote. It was the report of the 'Interdepartmental Committee on Physical Deterioration' appointed on 2 September 1902. ${ }^{17}$ Its secretary, then Mr. but now Sir Ernest Pooley, still happily survives.

The early origins of the Committee are somewhat singular. Following upon the South African War, which had thrown up much evidence of organizational and other deficiencies, there was a national stock-taking. In the course of this attention began to concentrate on the quality of the manhood which had sought to take part in the South African campaign, and comparisons were drawn between these volunteers and the British soldier of earlier wars.

The terms of reference were broadly drawn. The Committee was asked to advise how the Government and nation might be furnished with periodical 


\section{Blue Books}

data on the health and physique of the people, to indicate the causes of such physical deterioration as did exist in certain classes and to prescribe remedies. In effect the Committee concerned itself with the conditions which influenced the life of the juvenile population, at home, at school, in the factory and against the background of an urbanized environment. It examined sixtyeight witnesses, and reviewed everything that was relevant in the work of the responsible ministries.

In addition to the public heart-searchings to which the Committee owed its existence, there was the ponderous pronouncement of Professor Karl Pearson, the eminent statistician to be taken into account.

In his Huxley Lecture for I903, the Professor had pontificated thus:

Looking around impassionately from the calm atmosphere of anthropology, I fear there really does exist a lack of leaders of the highest intelligence, in science, in the arts, in trade, even in politics.

I do seem to see a want of intelligence in the British merchant, in the British professional man, and in the British workman.

We stand, I venture to think at the commencement of an epoch which will be marked by a great dearth of ability. ${ }^{18}$

But the Pearsonian pessimism was not general, and apart from the contributions of a few eccentrics, like the medical gentleman who attributed to an excess of uric acid not only the ailments of mankind, but also the deficiencies of the body politic, the evidence of witnesses was factual and realistic. Much of it touched on topics which we have already considered, but here and there were new facets of experience and a more modern outlook. Describing the life of a boy of fourteen in a factory, one of His Majesty's Inspectors said:

The hours will be long, fifty-five per week, and the atmosphere . . . very confined, perchance also dusty. Employment of this character rarely fosters growth . . . the stunted child elongates slightly, but remains very thin ... the legs are inclined to become bowed, the arch of the foot flattens, and the teeth decay.

For girls the picture was little different. They showed

the same shortness of stature, the same miserable physique ... the same sallow cheeks and carious teeth. At an age when girls ... under wholesome conditions usually possess a luxuriant growth of hair, these factory girls have a scanty crop-a wisp or a "rat's tail".

Factory life was preferred by many girls, and for these reasons:

At 13 years of age the majority have begun ... to handle their own earnings, to mix with a large number of people with all the excitement and gossip of factory life. They ... grow up entirely ignorant of everything pertaining to domesticity. After marriage therefore it is hardly probable that they would willingly relinquish this life to undertake work of which they are ... ignorant. 


\section{Sir Fohn Charles}

And yet there is evidence that the male of the species sometimes prevailed, for in Preston, we are told:

The men are said to look out for a wife who is a four loom weaver, and they have the reputation of being lazy.

In the factories and workshops of Finsbury, it was found that 80 per cent of the women and girls 'never touched solid feed till the middle of the day', and then pickles and vinegar, with tea, were the staple of that solid meal.

Light was shed on the stationary infantile mortality rate, which had remained virtually unchanged for over a quarter of a century.

In Burnley one woman had had twenty children and buried sixteen, all dying between the ages of one and eleven months. In Scotland-

it is quite a common thing to find a woman who has had as many as thirteen children, and lost eleven or twelve out of that number.

Then and now the decrease in breast-feeding in all classes was admitted and deplored. It was known in Liverpool that for every death among breast-fed infants under six months, there were twenty-two among infants entirely fed on artificial food.

Underfeeding of schoolchildren received special attention. The whole issue was pertinently put by the London editor of the Manchester Guardian:

We must face the question whether the logical culmination of free education is not free meals in some form or another.

Dr. Eicholz, one of the Government Inspectors of Schools, estimated that I22,000 or I 6 per cent of the schoolchildren of London were underfed, and in a bad school he had found 90 per cent of the scholars were unable because of their physical condition to attend properly to their work.

I have mentioned only a fraction of the subjects to which the Committee applied its corporate mind. Its other interests ranged from accidents in the home, to the association of insanity with rising wages.

Constituted on 2 September 1903, the Committee completed its labours in less than eleven months, and issued its report, complete with fifty-three recommendations. Amongst them were many novel suggestions, the vitality of which strikes one after fifty years. A great many were speedily brought within the ambit of legislation, others more tardily. But the sheaf of achievement includes the feeding of schoolchildren, their regular medical inspection, the instruction of girls in cookery, hygiene and domestic economy, the avoidance of fatigue amongst women and young persons in industry, the provision of maternity benefits through insurance, the registration of still-births, and the establishment of day nurseries. It is clear that the 


\section{Blue Books}

Committee had somehow escaped the calm and impassionate atmosphere of anthropology.

We have looked into half a dozen Blue Books, spread over seventy years, touching nothing later than I904. The succeeding half-century could have yielded just as many examples, but the illustrations would have been less colourful. One could have drawn a fruitful dredge through the monumental minority report of the Poor Law Commission of 1905, a report which Sidney Webb wrote out in his own long-hand, for his wife Beatrice, the Member of the Commission. Then there was the report into the Anti-Tuberculosis Services in Wales and Monmouth which in $193^{8}$ enumerated the factors militating against any successful onslaught upon the disease-national characteristics summed up in the phrase 'the natural fatalism of the Celtic people', and on the other hand the sordid arrangements of the Anglesey house-kitchen, siamber and grog-loft, with overcrowding that in one instance was described as being worse than anything in the native quarters of Shanghai. Or again, there is the Beveridge Report of 1942, which provided the blue-print for the system of Social Security, and gave notice of eviction to the 'five giants on the road to reconstruction', the giants of Want-'in some ways the easiest to attack'-and the others, 'Disease, Ignorance, Squalor and Idleness'. But further quotations, however informative, could not have added much to the moral which purports to adorn this tale. And that moral is to this simple effect. In history, and in medicine and science, a rediscovery of the original sources is never unprofitable. The protocols of the Jenners, Pasteurs, Dales, Bantings and Flemings, the case records of the Morgagnis, Sydenhams and Heberdens have all a refreshing starkness and simplicity. To read any one of them is to share with the writer the moments of his inspiration. And in the study of a period or a branch of history the need to come to grips with the contemporary record is just as great. Historical material as now construed and defined is almost without limit in its abundance. The potsherds and papyri, the charters and rolls, the letters and trivial domestic documents, the local annals, the ephemeral press, the obituaries, the parliamentary papers-from these one can catch the clear, authentic note without the overtones of any interpreting voice. It is more important to have pondered over an historical document, to have made one's own individual assessment of its significance than to have studied three or four summaries of its contents, each inevitably coloured, to a greater or less degree, by the personal background, experience and emotions of another reader. Commentary and criticism have their proper place, and so also lucid condensation, pyschological analysis and persuasive narrative. But until the protocols and their equivalent have had an opportunity of disclosing their secrets all these auxiliaries, which have so much to 
commend them as labour-saving and even literary devices, may be nothing but impediments to the questing student.

There is a vivid, revealing phrase in George Macaulay Trevelyan's essay on 'Clio', the muse of history, which is the epitome of all this: 'For only the documents can tell us the truth'. ${ }^{19}$ These documents, parliamentary papers, Blue Books are the seed of legislative oaks of the future.

\section{REFERENCES}

1. Third Report from Select Committee on Committee Rooms and Printed Papers, Selection of Printed Reports, etc. 1825 , p. 9.

2. Catalogue of Parliamentary Papers, r8or-rgoo. [1904], p. vii verso. P. S. King \& Son.

3. Cholera morbus. Copies of Extracts of all Information . . . relating to the Nature and Extent of any Infectious Disease prevailing in the Eastern Parts of Europe. 1831.

4. East India (Inoculation against Cholera and Typhoid). Return to an Address of the House of Commons dated Fune 29th, 1900. Cited in Brit. Med. J., 1900, 2, 587.

5. Report from the Poor Law Commissioners on an Inquiry into the Sanitary Condition of the Labouring Population of Great Britain. 1842.

6. Report on the Sanitary Condition of the Labouring Population of Great Britain. A Supplementary Report on the Practice of Interment in Towns. By Edwin CHADwIak. 1843.

7. Second Report of the Commissioners for Inquiring into the State of Large Towns and Populous Districts. 2 vols. 1845 .

8. First Annual Report of the Registrar-General of Births, Deaths, and Marriages in England. 1839, p. 88.

9. Ibid., p. 87 .

10. Tenth Annual Report of the Registrar-General of Births, Deaths, and Marriages in England, 1847 . I852, p. xv.

I1. Report on Poisoning, and the Dispensing, Vending, and Keeping of Poisons. By Alfred SwaIne TAylor. Appendix No. 16 to Sixth Annual Report of the Medical Officer of the Privy Council. 1864, p. 743 .

12. Report by Dr. Edward Smith on the Food of the Poorer Labouring Classes in England. Appendix No. 6 to Sixth Annual Report of the Medical Officer of the Privy Council. 1863, p. 2 r6.

13. Report by Dr. William Ord on the Sanitary Circumstances of Dressmakers and other Needlewomen in London. Appendix No. Io to Sixth Annual Report of the Medical Officer of the Privy Council. 1863 , p. 362 .

14. Report by Dr. Henry Julian Hunter on the Excessive Mortality of Infants in some Rural Districts of England. Appendix No. 14 to Sixth Annual Report of the Medical Officer of the Privy Council. I863, p. 454 .

15. Simon, Sir. J. English Sanitary Institutions. 189o, p. 298.

16. Fraze R, W. M. A History of English Public Health, 1834-1939. 1950, p. 120.

17. Report of the Inter-Departmental Committee on Physical Deterioration. 1904.

18. PE ARSON, K. F. R. anthrop. Inst. I903, XXxiII, I 79.

19. TRE velyan, G. M. Clio, a Muse and other Essays Literary and Pedestrian. I913, p. I 7.

As many of these original reports are not easily accessible, it may be noted that long extracts from them are given in Public Health Reports, by John Simon, G.B., F.R.S. 2 vols. London, 1887. Simon's English Sanitary Institutions, 2nd ed., London, 1897, should also be consulted. 